\title{
GMR
}

\section{Genetic diversity of Saccharum complex using ISSR markers}

\author{
L.A.R. Oliveira ${ }^{1}$, C.A. Machado ${ }^{1}$, M.N. $\operatorname{Cardoso}^{1}$, A.C.A. Oliveira ${ }^{1}$, \\ A.L. Amaral ${ }^{2}$, A.R.C. Rabbani ${ }^{3}$, A.V.C. Silva ${ }^{2}$ and A.S. Ledo ${ }^{2}$ \\ ${ }^{1}$ Programa de Pós-Graduação em Agricultura e Biodiversidade, \\ Universidade Federal de Sergipe, Aracaju, Sergipe, Brasil \\ ${ }^{2}$ Embrapa Tabuleiros Costeiros, Aracaju, Sergipe, Brasil \\ ${ }^{3}$ Instituto Federal da Bahia, Porto Seguro, Bahia, Brasil \\ Corresponding author: L.A.R. Oliveira \\ E-mail: leila.a.resende@gmail.com
}

Genet. Mol. Res. 16 (3): gmr16039788

Received July 28, 2017

Accepted August 18, 2017

Published September 21, 2017

DOI http://dx.doi.org/10.4238/gmr16039788

Copyright $(2017$ The Authors. This is an open-access article distributed under the terms of the Creative Commons Attribution ShareAlike (CC BY-SA) 4.0 License.

\begin{abstract}
Sugarcane (Saccharum sp, Poaceae) is native to Southeast Asia, and due to growing demand as raw material, its cultivation recently expanded to new frontiers. The genetic diversity analysis is essential for targeting strategies in the formation and maintenance of a germplasm. This study aimed to assess the genetic diversity of 26 accessions of sugarcane from the Active Germplasm Bank of Embrapa Coastal Tablelands, using inter-simple sequence repeat (ISSR) molecular markers. Sixteen primers were used, resulting in 87 fragments with $91.13 \%$ of polymorphism. The similarity of the individuals ranged between 0.22 and 0.87 . Individuals RB867515 and RB92579 were closer genetically, and the most distant ones were PI240785 and NSL 291970. Four distinct clusters were formed, using UPGMA. This information can be used to prioritize the selection of accessions for the conduction of hybridization in breeding and germplasm exchange actions.
\end{abstract}

Key words: S. officinarum; S. robustum; S. sinensis; S. spontaneum; ISSR molecular markers 


\section{INTRODUCTION}

Sugarcane (Saccharum sp) is a plant of the Poaceae family, native to Southeast Asia, and cultivated in tropical and subtropical regions (Casu et al., 2004). Its cultivation expanded to new frontiers recently due to growing demand as raw material (biomass) for ethanol production and power generation, as a source of several new added-value products along with sugar production (Santos et al., 2012).

The genus Saccharum includes six species: noble cane, $S$. officinarum $(2 \mathrm{n}=80)$, two wild species, $S$. robustum $(2 \mathrm{n}=60-80)$ and $S$. spontaneum $(2 \mathrm{n}=40-128)$, and three secondary species, $S$. barberi $(2 \mathrm{n}=81-124), S$. sinense $(2 \mathrm{n}=111-120)$ and $S$. edule $(2 \mathrm{n}=60,70,80) . S$. officinarum, $S$. spontaneum and $S$. robustum represent the basic species, and $S$. barberi and $S$. sinense are secondary species probably derived from the hybridization of $S$. officinarum and S. spontaneum. All species cited along with the genera Erianthus, Miscanthus, Narenga, and Sclerostachya constitute the "Saccharum complex" (Daniels et al., 1975).

As there is the need to diversify the genetic basis of modern cultivars to meet an increasingly competitive market, mainly because they derive from exclusive backcrosses involving a few clones of $S$. officinarum and S. spontaneum (Shrivastava and Srivastava, 2016), it is extremely important to characterize cultivars worldwide (Almeida et al., 2009).

As a result, breeding programs of sugarcane have emerged worldwide. In Brazil, the Brazilian Agricultural Research Corporation (EMBRAPA) started to study energy derived from sugarcane to provide genetic material with high levels of biomass adapted to different regions of cultivation. Embrapa Coastal Tablelands located in Sergipe, Northeast region, has kept 128 accessions in an Active Germplasm Bank, including the genera Saccharum, Erianthus, and Miscanthus, derived from collections in Brazil and from imports and exchanges with international institutions, where the molecular characterization for the identification of genetic diversity has been held.

The possibility of accessing the genetic variability directly at DNA level enables precise techniques that assist the process of intellectual protection of genetic materials. The molecular markers are important tools for the breeding of plants and aim at the mapping of genes, genetic diversity analysis, disease diagnostics, and taxonomic and evolutionary studies (Wünsch and Hormaza, 2007). In sugarcane, some studies have been conducted to identify the genetic diversity among genotypes using AFLP (Selvi et al., 2006), RAPD (Khan et al., 2009; Ullah et al., 2013), chloroplast microsatellite markers (coSSR) (Raj et al., 2016), SSR (Pandey et al., 2011) and inter-simple sequence repeat (ISSR) (Srisvastava and Gupta, 2008; Almeida et al., 2009; Devarumath et al., 2012; Rao et al., 2016). RAPD and ISSR have been amplified for water stress tolerance in sugarcane varieties (Fahmy et al., 2008).

The aim of this study was to assess the genetic diversity of sugarcane accessions from the Active Germplasm Bank of Embrapa Coastal Tablelands using ISSR molecular markers, for selection of accessions aiming the conduction of hybridization in breeding programs and germplasm exchange.

\section{MATERIAL AND METHODS}

Twenty-four sugarcane accessions established in vitro were used, from the second subculture, provided by the National Center for Genetic Resources Preservation/ARS/ USDA, Fort Collins, CO, USA, and two varieties "RB" from Inter-University Network for

Genetics and Molecular Research 16 (3): gmr16039788 
the Development of Sugarcane Industry, characterized as varieties cultivated in Brazil (Table 1). All accessions are from the Active Germplasm Bank of the Saccharum Complex from Embrapa Coastal Tablelands, located in the Experimental Field Jorge Prado Sobral, located in Nossa Senhora das Dores, Sergipe, Brazil, (10²9’27’'S; 37¹1’34”W).

Young leaves from 26 accessions were collected, identified, packed in Styrofoam plastic bags with ice, and stored at $-80^{\circ} \mathrm{C}$ at the Molecular Biology Laboratory of Embrapa Coastal Tablelands.

\begin{tabular}{|c|c|c|}
\hline Number & Identification of accession & Species \\
\hline 1 & Q 45866 & Saccharum officinarum \\
\hline 2 & Q 46199 & Saccharum robustum \\
\hline 3 & Q 45251 & Saccharum robustum \\
\hline 4 & Q 42509 & Saccharum $\mathrm{spp}$ \\
\hline 5 & Q 45911 & Saccharum officinarum \\
\hline 6 & Q 45864 & Saccharum officinarum \\
\hline 7 & Q 44830 & Saccharum officinarum \\
\hline 8 & Q 45337 & Saccharum hybrid \\
\hline 9 & Q 45416 & Saccharum $\mathrm{spp}$ \\
\hline 10 & Q 44890 & Saccharum officinarum \\
\hline 11 & Q 44833 & Saccharum officinarum \\
\hline 12 & Q 45869 & Saccharum officinarum \\
\hline 13 & Q 42433 & Saccharum hybrid \\
\hline 14 & PI 240785 Q 45923 NG 57-208 & Saccharum robustum \\
\hline 15 & PI 197800 Sumatra \#2 & Saccharum spontaneum \\
\hline 16 & Q 36830 MOL 6091 & Saccharum $\mathrm{sp}$ \\
\hline 17 & GH-49 UNKR65P35 & Saccharum robustum \\
\hline 18 & MIA 35303 MOL 6091 & Saccharum robustum \\
\hline 19 & NSL 291970 Glagh 1286 & Saccharum spontaneum \\
\hline 20 & PI 88652 NG 28213 & Saccharum officinarum \\
\hline 21 & MIA 35301 MOL 6089 & Saccharum robustum \\
\hline 22 & RB 867515 & Saccharum $\mathrm{sp}$ \\
\hline 23 & RB 92579 & Saccharum $\mathrm{sp}$ \\
\hline 24 & PI 495109 Q46207 IN 84-045 & Saccharum robustum \\
\hline 25 & PI 286657 SES-006 & Saccharum spontaneum \\
\hline 26 & PI 29109 & Saccharum sinensis \\
\hline
\end{tabular}

DNA extraction followed the $2 \%$ cetyltrimethyl ammonium bromide (CTAB) protocol (Romano and Brasileiro, 1999). Seventeen ISSR primers were used (University of British Columbia, Vancouver, Canada) to detect polymorphism at a concentration of $15 \mathrm{ng} /$ $\mathrm{mL}$. Primers were randomly selected. Polymerase chain reaction (PCR) amplifications were carried out in a thermocycler (Veriti, Applied Biosystems). Samples were initially subjected to denaturation at $94^{\circ} \mathrm{C}$ for $4 \mathrm{~min}$, followed by 37 amplification cycles. During each cycle, samples were subjected to denaturation at $94^{\circ} \mathrm{C}$ for $1 \mathrm{~min}$, annealing at different temperatures for $2 \mathrm{~min}$, and extension at $72^{\circ} \mathrm{C}$ for $2 \mathrm{~min}$.

Each ISSR reaction was carried out in a final volume of $20 \mathrm{~mL}$ containing $1.5 \mathrm{~mL} 15$ $\mathrm{ng} / \mathrm{mL}$ DNA; $0.2 \mathrm{~mL}$ Taq DNA polymerase (Invitrogen); $0.6 \mathrm{~mL} \mathrm{MgCl} ; 0.4 \mathrm{~mL}$ dNTP; $1 \mathrm{~mL}$ primer (oligonucleotides); $2 \mathrm{~mL}$ buffer; and $14.3 \mathrm{~mL}$ ultrapure water.

Fragments were visualized on $2 \%$ agarose gel (1X TBE; $89 \mathrm{mM}$ Tris; $89 \mathrm{mM}$ boric acid; 2.5 mM EDTA, $\mathrm{pH} 8.3$ ) in a horizontal electrophoresis system run at a constant voltage of $182 \mathrm{~V}, 91 \mathrm{~mA}$, and $17 \mathrm{~W}$ for $115 \mathrm{~min}$. For size standardization of bands, $5 \mu \mathrm{L} 100$-bp molecular weight marker was used. Gels were stained with ethidium bromide solution $(0.02 \mathrm{~mL} / \mathrm{mL}$ water), for approximately $30 \mathrm{~min}$, and then visualized under UV light, using the Loccus L-pix HE photodocumentation device (Loccus Biotecnologia, Brazil).

Genetics and Molecular Research 16 (3): gmr16039788 
Gel analysis resulted in a binary matrix according to the presence (1) or absence (0) of fluorescent bands. The percentage of polymorphic loci was calculated from the number of amplified bands. Similarity coefficients were calculated using the Jaccard index (Jaccard, 1908).

To determine the minimum number of amplified fragments needed for studies on genetic diversity, estimates were obtained from correlation $(\mathrm{r})$ of similarity matrix values and the stress value (E), which indicates the adjustment between the original matrix and the simulated matrix. The optimal number of fragments was calculated by means of the GENES software (Cruz, 2007) and considered satisfactory for the analysis when the stress value was less than 0.05 (Kruskal, 1964) and the correlation closer to 1.

From the similarity matrix, a dendrogram was generated by the unweighted pairgroup method with arithmetic mean (UPGMA). Bootstrapping was carried out with 10,000 replicates using the FreeTree software (Pavlícek et al., 1999). The TreeView software was also used to generate the dendrogram (Pavlícek et al., 1999). Samples were clustered considering the principal coordinates analysis (PCoA), with the aid of the Genalex v.p software (Peakall and Smouse, 2006). The Shannon index (I) (Brown and Weir, 1983) and the expected heterozygosity $\left(H_{\mathrm{E}}\right)$ (Lynch and Milligan, 1994) were also estimated using the Genalex 6.3 software (Peakall and Smouse, 2006).

\section{RESULTS AND DISCUSSION}

The individuals were analyzed based on 87 loci obtained from 16 ISSR primers. The optimal number to obtain the desired precision in the analysis of genetic diversity from Saccharum sp was after 83 fragments, when the stress value was 0.055 and the correlation (r) 0.991 (Figure 1).

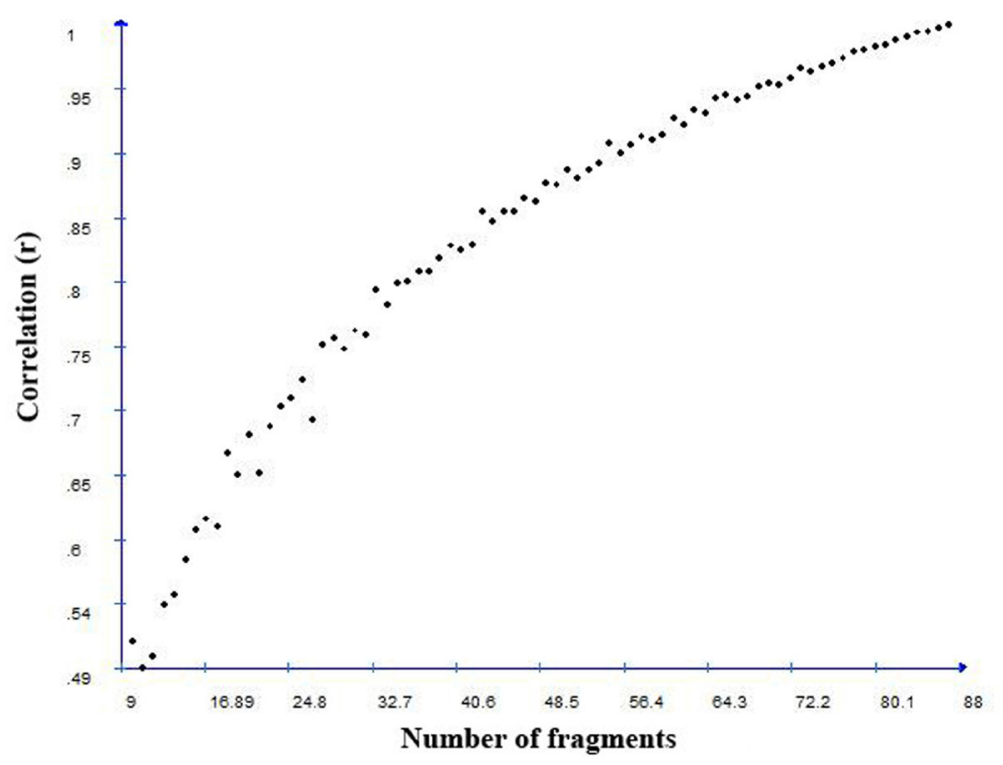

Figure 1. Correlation coefficient and number of fragments using ISSR markers between 26 individuals of sugarcane belonging to Embrapa Coastal Tablelands based on genetic similarities obtained by the bootstrap method.

Genetics and Molecular Research 16 (3): gmr16039788 
In this study, there was a directly proportional relationship between the number of amplified fragments and the correlation magnitude of the values of the original similarity matrix obtained from resampling with different numbers of amplified fragments. Thus, from the optimal number of fragments obtained (83), the correlation coefficient value approached the maximum value, which proves the consistency of the data with the number of primers used and the number of fragments obtained, being sufficient for the analyses of genetic diversity.

Among the 16 primers tested in the amplification of samples, 87 loci were generated, of which 80 primers were polymorphic $(91.13 \%)$. In each ISSR reaction, the total number of amplified fragments ranged from three (UBC-828, UBC-845, UBC-855) to twelve (UBC-815) (Table 2 and Figure 2).

Table 2. Inter-simple sequence repeat (ISSR) primers used in 26 sugarcane accessions from the Active Germplasm Bank of Embrapa Coastal Tablelands, Brazil, with their respective sequences, annealing temperature (AT), number of fragmented bands (NFB), polymorphism percentage $(\% \mathrm{P})$, Shannon Index $(\mathrm{I})$, and expected heterozygosity $\left(H_{\mathrm{E}}\right)$.

\begin{tabular}{l|l|c|c|c|c|c}
\hline Primers & Sequence $\left(5^{\prime}-3^{\prime}\right)$ & AT $\left({ }^{\circ} \mathrm{C}\right)$ & NFB & $\% \mathrm{P}$ & $\mathrm{I}$ & $H_{\mathrm{E}}$ \\
\hline 807 & AGA GAG AGA GAG AGA GT & 47 & 4 & 100 & 0.53 & 0.36 \\
\hline 812 & GAG AGA GAG AGA GAG AA & 54.8 & 7 & 100 & 0.48 & 0.31 \\
\hline 815 & CTC TTC TCT CTC TCT CTG & 47.6 & 12 & 100 & 0.49 & 0.32 \\
\hline 816 & CAC ACA CAC ACA CAC AT & 54.8 & 5 & 100 & 0.37 & 0.22 \\
\hline 818 & CAC ACA CAC ACA CAC AG & 57.2 & 4 & 100 & 0.44 & 0.28 \\
\hline 825 & ACA CAC ACA CAC ACA CT & 54.8 & 7 & 85.7 & 0.43 & 0.29 \\
\hline 826 & ACA CAC ACA CAC ACA CC & 57.2 & 5 & 100 & 0.48 & 0.31 \\
\hline 827 & ACA CAC ACA CAC ACA CG & 57.2 & 5 & 100 & 0.60 & 0.41 \\
\hline 828 & TGT GTG TGT GTG TGT GA & 54.8 & 3 & 100 & 0.24 & 0.14 \\
\hline 835 & AGA GAG AGA GAG AGA GYC & 58.8 & 7 & 100 & 0.56 & 0.38 \\
\hline 841 & GAG AGA GAG AGA GAG AYC & 48.5 & 5 & 20 & 0.12 & 0.08 \\
\hline 845 & CTC TCT CTC TCT CTC TRG & 48.1 & 3 & 66.7 & 0.38 & 0.26 \\
\hline 851 & GTG TGT GTG TGT GTG TYG & 49.2 & 4 & 100 & 0.67 & 0.48 \\
\hline 855 & ACA CAC ACA CAC ACY T & 53.1 & 3 & 100 & 0.60 & 0.41 \\
\hline 856 & ACA CAC ACA CAC ACA CYA & 56.4 & 7 & 85.7 & 0.43 & 0.28 \\
\hline 887 & DVD TCT CTC TCT CTC CT & 55.6 & 6 & 100 & 0.42 & 0.27 \\
\hline Total average & & & 5.44 & 91.13 & 0.45 & 0.30 \\
\hline
\end{tabular}

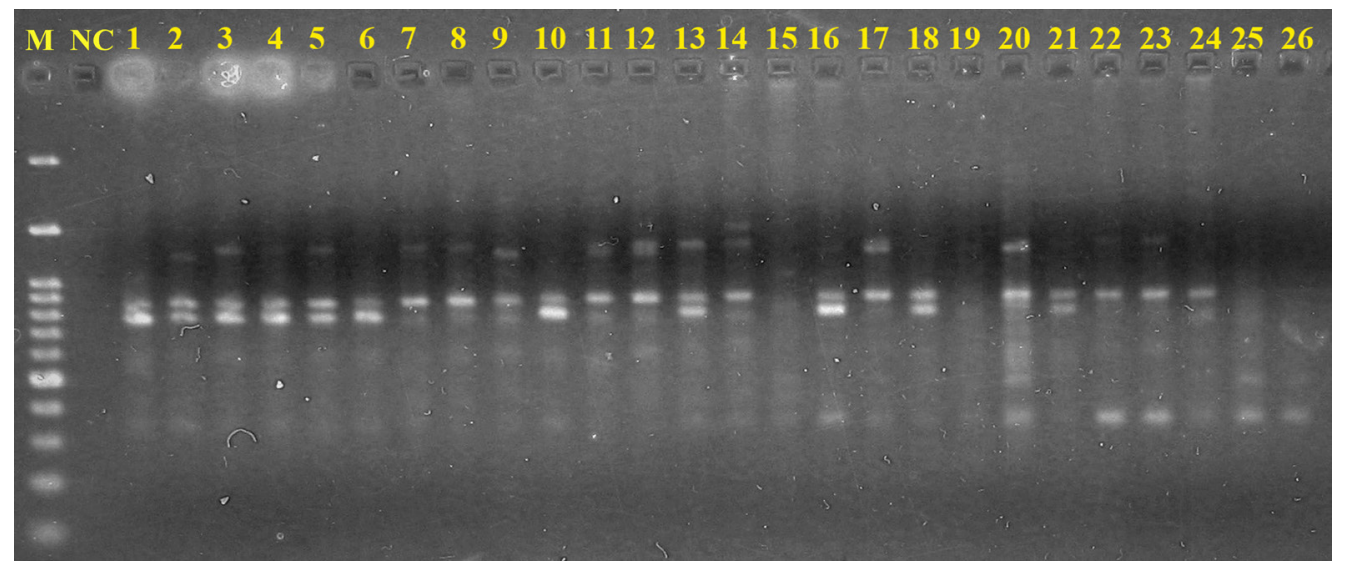

Figure 2. Electrophoretic profiles of inter simple sequence repeats of 26 sugarcane accessions amplified in agarose gel using the primer UBC 887. Embrapa Coastal Tablelands, Brazil. Lane $M=100$-bp marker; lane $N C=$ negative control; lanes 1 to $26=$ DNA samples.

Genetics and Molecular Research 16 (3): gmr16039788 
Several markers have been used for studies on sugarcane diversity. AFLP, which presents advantages such as the detection of the highest number of locus, was used by Selvi et al. (2006) in species of the genus Saccharum and obtained 1323 bands with 12 pairs of primers, from which $1122(84.8 \%)$ were polymorphic. Ullah et al. (2013) used eight RAPD markers and observed $73.5 \%$ polymorphism between the five varieties studied. In a study conducted with 20 accessions of S. officinarum in Pakistan, Khan et al. (2009) showed 86.8\% polymorphism for 188 of the 210 polymorphic fragments obtained by the use of 21 RAPD primers. Raj et al. (2016), analyzing the genetic diversity of the Saccharum complex, using coSSR, found polymorphic amplifications $(100 \%)$ in nine primers by amplifying 54 fragments . Pandey et al. (2011), however, found 148 polymorphic bands in five SSR primers.

Almeida et al. (2009) found high polymorphism (95\%) using seven ISSR primers; of the 56 fragments obtained, 53 were polymorphic. Srivastava and Gupta (2008), when analyzing the diversity of 40 genotypes of sugarcane, found 79 bands amplified by 10 ISSR primers, from which $62(78.48 \%)$ were polymorphic and 17 were monomorphic. Devarumath et al. (2012) found the production of 65 amplified fragments, with $96.5 \%$ polymorphism, in 13 ISSR primers used for PCR amplification. Rao et al. (2016), for ISSR analysis, used 19 primers in 14 genotypes of sugarcane for amplification of the PCR, a total of 164 bands were marked with 109 polymorphic bands and 55 monomorphic bands. These results, as well as in this study, prove the efficiency of ISSR when compared with other markers, revealing a high degree of polymorphism.

The I ranged from 0.12 to 0.67 , with an average of 0.45 . The $H_{\mathrm{E}}$ ranged from 0.08 to 0.48 , with an average of 0.30 (Table 3 ). Those indexes showed intermediate levels of genetic diversity. However, for some initiators, such as 827,851 and 855 , the values of I and $H_{\mathrm{E}}$ can be considered high, showing high variability. According to Giustina et al. (2014), the value of I can vary between 0 and 1, with a value of 1 indicating the highest diversity of a population. The values found in this study are close to those verified by Nayak et al. (2014) in S. spontaneum, S. officinarum, S. hybrid, S. barberi, S. robustum, and S. sinense, in which the values of I found were between 0.38 and 0.49 and of $H_{\mathrm{E}}$ were between 0.23 and 0.30 .

The polymorphic information content (PIC) indicates how much the marker used shows of polymorphic information in studies on genetic diversity. Values above 0.5 are highly informative; those between 0.25 and 0.50 are moderately informative; and values below 0.25 are considered slightly informative (Botstein et al. 1980). In this study, the PIC value was 0.28 , considered moderately informative.

The Jaccard similarity coefficient ranged between 0.22 and 0.87 , with an average of 0.49 , which indicates a relatively high genetic diversity. The accessions RB867515 and RB92579, both Saccharum sp, were the most similar genetically, with 0.87 index. On the other hand, the pair of accessions PI240785 and NSL 291970, S. robustum and S. spontaneum, respectively, showed less genetic similarity $(0.22)$.

The polymorphism identified by the markers was used to create a matrix of genetic distance. Four main clusters were identified in UPGMA analysis based on the Jaccard coefficient (Figure 3). The further individual, PI240785, is in the cluster C1. Most of the accessions (all from Queensland, Australia) was allocated in a main cluster C2, with several subclusters, Q45866 and Q46199 being the closest ones (0.77) of that group.

The second main cluster, $\mathrm{C} 3$, has eight separate individuals in subclusters, with individuals RB867515 and RB92579 possessing greater similarity (0.87). The cluster C4, however, was isolated from others and had all accessions of S. spontaneum and S. sinensis separated into two subclusters with similarity of 0.73 between PI286657 and PI29109.

Genetics and Molecular Research 16 (3): gmr16039788 
Genetic diversity of Saccharum complex

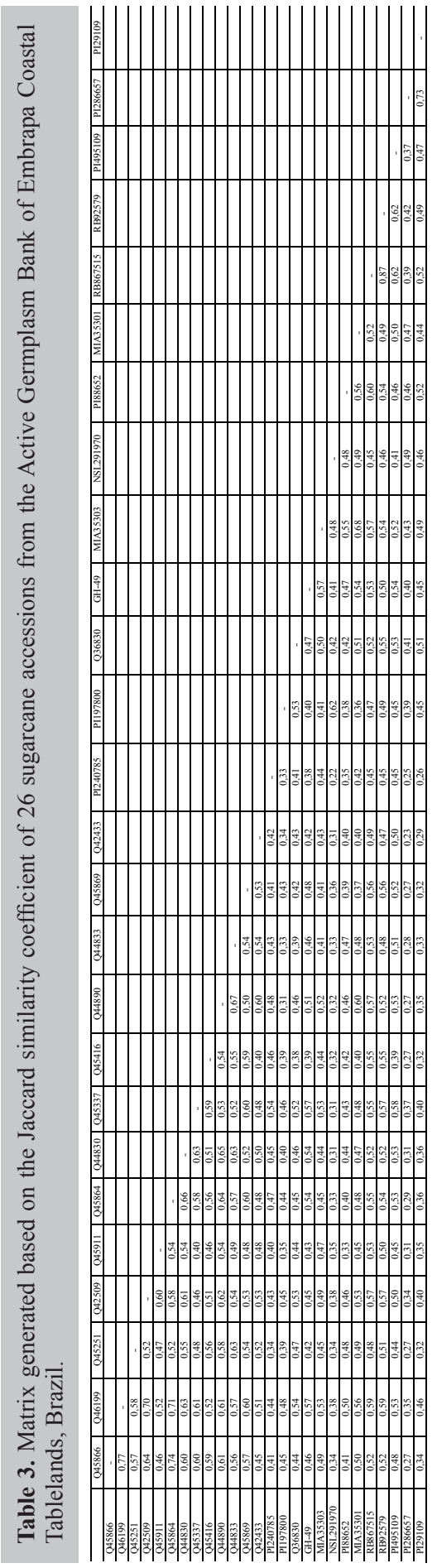

Genetics and Molecular Research 16 (3): gmr16039788 
Despite the large distribution of accessions in most groups, indicating great genetic diversity, these were not separated by a group of the same species in each subcluster, which can be explained by the existence of common alleles among different species, since they are of the same genus. Similar results were found by Raj et al. (2016), in which there was a close relationship among the different species that constitute the Saccharum complex; with $S$. spontaneum, however, contributing to greater diversity. According to the authors, $S$. spontaneum is known to be a highly variable species regarding morphology, geographical distribution, and chromosome number $(2 \mathrm{n}=48-128)$. High divergence of $S$. spontaneum from the rest of the species Saccharum was also reported by Alwala et al. (2006).

Selvi et al. (2006), however, found divergent results, in which the genus Saccharum was organized in a large cluster, but with each group of species in separate subclusters.

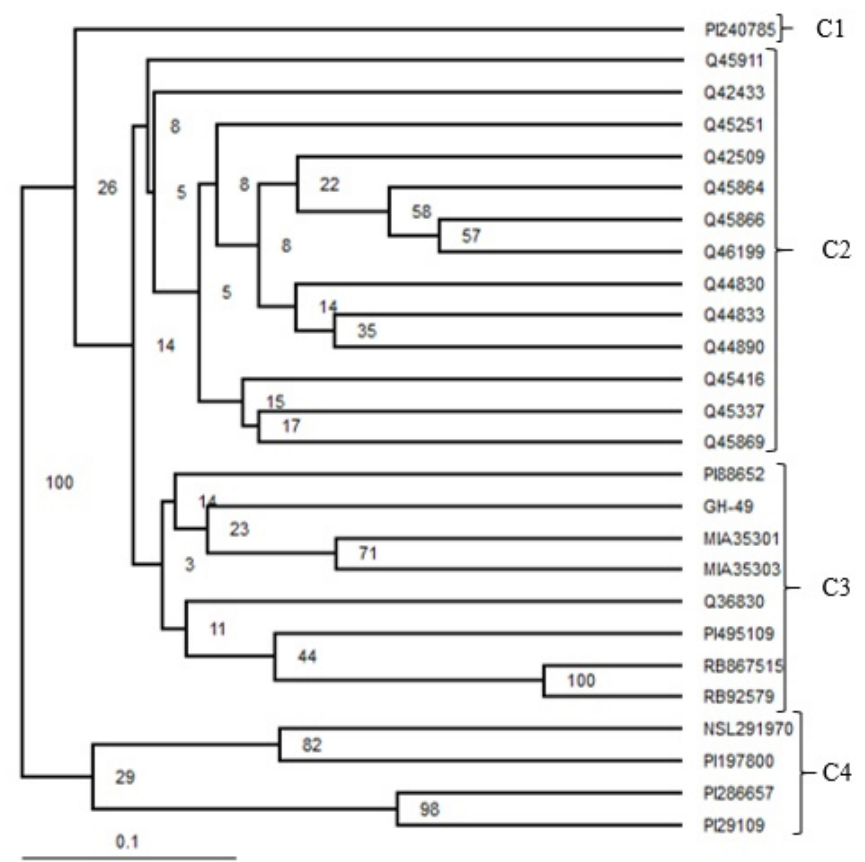

Figure 3. Phylogenetic representation of unweighted pair group method using arithmetic averages (UPGMA) clustering estimated by the genetic similarity of the Jaccard coefficient and by the bootstrap analysis $(10,000 \mathrm{X})$ for 26 sugarcane accessions from the Active Germplasm Bank of Embrapa Coastal Tablelands, Brazil.

The genetic distances were also assessed by the PCoA (Figure 4). Four clusters were identified among the different accessions studied, and the amount of the first two main components was $49.30 \%$. These results stress the efficiency of ISSR in genetic diversity detection among the accessions of sugarcane. According to the results of UPGMA, some pairs of individuals (RB867515/RB92579, PI286657/PI29109, Q45866/Q46199, Q44833/Q44890, Q45337/Q45869) were genetically very close in PCoA, showing that the use of more than one clustering method prevents interference to be adopted in the allocation of materials within a specific genotypic subcluster (Silva et al., 2011).

Genetics and Molecular Research 16 (3): gmr16039788 


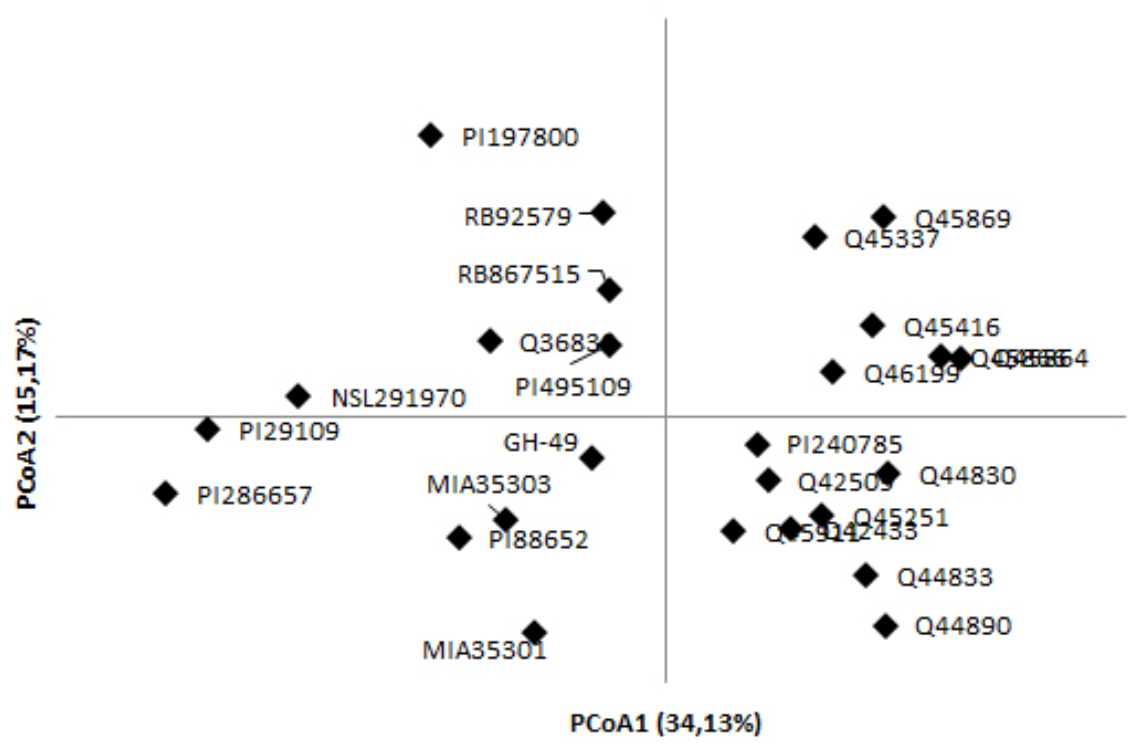

Figure 4. Principal coordinates analysis (PCoA) of 26 sugarcane accessions from the Active Germplasm Bank of Embrapa Coastal Tablelands, Brazil.

\section{CONCLUSIONS}

The genetic diversity of sugarcane genotypes from the Active Germplasm Bank of Embrapa Coastal Tablelands is considered high. The pair of individuals with less genetic similarity was PI240785 and NSL 291970, S. robustum and S. spontaneum respectively.

The results found in this study showed the level of genetic resolution and reliability obtained by analysis with ISSR molecular markers allowed the discrimination of different genetically accessions, which could be used for the management of genetic resources of the species and, once selected, will be important for breeding programs aimed at selection of superior genotypes.

\section{REFERENCES}

Almeida CMA, Lima SEN, Lima GSA, Brito JZ, et al. (2009). Caracterização molecular de cultivares de cana-de-açúcar utilizando marcadores ISSR. Cienc. Agrotec. 33: 1771-1776. https://doi.org/10.1590/S1413-70542009000700012

Alwala S, Suman A, Arro JA, Veremis JC, et al. (2006). Target region amplification polymorphism (TRAP) for accessing genetic diversity in sugarcane germplasm collections. Crop Sci. 46: 448-455. https://doi.org/10.2135/ cropsci2005.0274

Botstein D, White RL, Skolnick M and Davis RW (1980). Construction of a genetic linkage map in man using restriction fragment length polymorphisms. Am. J. Hum. Genet. 32: 314-331.

Brown AHD and Weir BS (1983). Measuring genetic variability in plant populations. In: Isozymes in Plant Genetics and Breeding, Part A (Tanksley SD and Orton TJ, eds.). Elsevier Science, Amsterdam, 219-239.

Casu RE, Dimmock CM, Chapman SC, Grof CPL, et al. (2004). Identification of differentially expressed transcripts from maturing stem of sugarcane by in silico analysis of stem expressed sequence tags and gene expression profiling. Plant Mol. Biol. 54: 503-517. https://doi.org/10.1023/B:PLAN.0000038255.96128.41

Cruz CD (2007). Genes: Aplicativo computacional em genética e estatística. UFV, Viçosa.

Daniels J, Smith P, Panton N and Williams CA (1975). The origin of the genus Saccharum. Sugarcane Breed. Newsl 36: 24-39.

Genetics and Molecular Research 16 (3): gmr16039788 
Devarumath BM, Kalwade SB, Kawar PG and Sushir KV (2012). Assesment of genetic diversity in sugarcane germoplasm using ISSR and SSR markers. Sugar Tech 14: 334-344. https://doi.org/10.1007/s12355-012-0168-7

Fahmy EM, El-Gawad NMA, El-Geddawy IH, Saleh OM, et al. (2008). Development of RAPD and ISSR markers for drought tolerance in sugarcane (Saccharum officinarum L.). Egypt. J. Genet. Cytol. 37: 1-15.

Giustina LD, Luz LN, Vieira FS, Rossi FS, et al. (2014). Population structure and genetic diversity in natural populations of Theobroma speciosum Willd. Ex Spreng (Malvaceae). Genet. Mol. Res. 13: 3510-3519. https://doi.org/10.4238/2014. February. 14.5

Jaccard P (1908). Nouvelles recherches sur la distribution florale. Bull. Soc. Vaud. Sci. Nat. 44: 223-270.

Khan FA, Khan A, Azhar FM and Rauf S (2009). Genetic diversity of Saccharum officinarum accessions in Pakistan as revealed by random amplified polymorphic DNA. Genet. Mol. Res. 8: 1376-1382. https://doi.org/10.4238/vol84 gmr665

Kruskal JB (1964). Multidimensional scaling by optimizing goodness of fit to a nonmetric hypothesis. Psychometrika 29: 1-27. https://doi.org/10.1007/BF02289565

Lynch M and Milligan BG (1994). Analysis of population genetic structure with RAPD markers. Mol. Ecol. 3: 91-99. https://doi.org/10.1111/j.1365-294X.1994.tb00109.x

Nayak SN, Song J, Villa A, Pathak B, et al. (2014). Promoting utilization of Saccharum spp. genetic resources through genetic diversity analysis and core collection construction. PLoS One 9: e110856. https://doi.org/10.1371/journal. pone. 0110856

Pandey A, Mishra RK, Mishra S, Singh YP, et al. (2011). Assessment of genetic diversity among sugarcane cultivars (Saccharum officinarum L.) using simple sequence repeats markers. Online J. Biol. Sci. 11: 105-111. https://doi. org/10.3844/ojbsci.2011.105.111

Pavlícek A, Hrdá S and Flegr J (1999). Free-Tree - freeware program for construction of phylogenetic trees on the basis of distance data and bootstrap/jackknife analysis of the tree robustness. Application in the RAPD analysis of genus Frenkelia. Folia Biol. (Praha) 45: 97-99.

Peakall R and Smouse PE (2006). Genalex 6: genetic analysis in Excel. Population genetic software for teaching and research. Mol. Ecol. Resour. 6: 288-295. https://doi.org/10.1111/j.1471-8286.2005.01155.x

Raj P, Selvi A, Prathima PT and Nair NV (2016). Analysis of genetic diversity of Saccharum complex using chloroplast microsatellite markers. Sugar Tech 18: 141-148. https://doi.org/10.1007/s12355-015-0382-1

Rao VP, Singh S, Chaudhary R, Sharma MK, et al. (2016). Genetic variability in sugarcane (Saccharum spp. Hybrid) genotypes through inter simple sequence repeats (ISSR) markers. J. Appl. Nat. Sci. 8: 1404-1409.

Romano E and Brasileiro ACM (1999). Extração de DNA de plantas. Biotecnolog. Cienc. Desenvolv. 9: 40-43.

Santos JM, Duarte Filho LSC, Soriano ML, Silva PP, et al. (2012). Genetic diversity of the main progenitors of sugarcane from the RIDESA germplasm bank using SSR markers. Ind. Crops Prod. 40: 145-150. https://doi.org/10.1016/j. indcrop.2012.03.005

Selvi A, Nair NV, Noyer JL, Singh NK, et al. (2006). AFLP analysis of the phenetic organization and genetic diversity in the sugarcane complex, Saccharum and Erianthus. Genet. Resour. Crop Evol. 53: 831-842. https://doi.org/10.1007/ s10722-004-6376-6

Shrivastava AK and Srivastava S (2016). Diversity of the germplasm of Saccharum species and related genera available for use in directed breeding programs for sugarcane improvement. Curr. Sci. 111: 475-482. https://doi.org/10.18520/ cs/v111/i3/475-482

Silva AVC, Santos ARF, Wickert E, Silva JFS, et al. (2011). Diversidade genética entre acessos de mangabeira (Hancornia speciosa Gomes). Agraria 6: 572-578. https://doi.org/10.5039/agraria.v6i4a943

Srivastava S and Gupta OS (2008). Inter simple sequence repeat profile as a genetic marker system in sugarcane. Sugar Tech 10: 48-52. https://doi.org/10.1007/s12355-008-0008-y

Ullah SMS, Hossain MA, Hossain MM, Barman S, et al. (2013). Genetic diversity analysis of chewing sugarcane (Saccharum officinarum L.) varieties by using RAPD markers. J. Biosci. Biotechnol. 2: 145-150.

Wünsch A and Hormaza JI (2007). Characterization of variability and genetic similarity of European pear using microsatellite loci developed in apple. Sci. Hortic. (Amsterdam) 113: 37-43. https://doi.org/10.1016/j.scienta.2007.02.002

Genetics and Molecular Research 16 (3): gmr16039788 